\title{
SUBSTITUSI PASTA UBI JALAR UNGU TERHADAP MUTU KIMIA, NILAI ENERGI DAN MUTU ORGANOLEPTIK COOKIES (KUE KERING) SEBAGAI ALTERNATIF SNACK PENDERITA DIABETES MELITUS
}

\author{
Sweet Potato Substitution On Purpose Of Chemical Quality, Energy Value And Quality \\ Of Organoleptic Cookies (Dry Cake) As An Alternative Snack Diabetes Melitus Patients
}

\author{
Zeni Nur Hidayati, I Komang Suwita \\ Jurusan Gizi Poltekkes Kemenkes Malang \\ Email : ksuwita@gmail.com
}

\begin{abstract}
ABSTRAK
Kandungan serat yang tinggi dalam makanan akan mempunyai indeks glikemik yang rendah sehingga dapat memperpanjang pengosongan lambung. Keberadaan antosianin dalam makanan juga sangat penting, karena antosianin juga memiliki kemampuan dapat mencegah gangguan pada fungsi hati dan menurunkan kadar gula darah. Penelitian ini bertujuan untuk menganalisis pengaruh substitusi pasta ubi jalar ungu terhadap mutu kimia, nilai energi dan mutu organoleptik pada cookies (kue kering) sebagai alternatif snack penderita diabetes mellitus. Jenis penelitian ini adalah eksperimen laboratorium dengan desain percobaan Rancangan Acak Lengkap (RAL) dengan taraf perlakuan substitusi pasta ubi jalar ungu : 24\%, 32\%, 40\%, dan dilakukan replikasi sebanyak 3 kali setiap taraf perlakuan. Analisis statistik yang digunakan untuk mutu kimia dan energi adalah One Way Anova, dan untuk mutu organoleptik adalah Kruskall Wallis dengan tingkat kepercayaan 95\%. Hasil penelitian menunjukan bahwa besarnya proporsi pasta ubi jalar ungu yang digunakan memberikan pengaruh yang signifikan terhadap kadar air, kadar abu, kadar protein, kadar lemak, kadar karbohidrat, nilai energi dan kadar serat. Substitusi pasta ubi jalar ungu memberikan pengaruh yang signifikan terhadap warna, aroma, tekstur, dan rasa pada cookies. Perlakuan dengan proporsi pasta ubi jalar ungu 40\% (P3) dengan karbohidrat $(55,27 \mathrm{~g})$, serat tertinggi $(2,81 \mathrm{~g})$ dapat direkomendasikan sebagai taraf perlakuan terbaik.
\end{abstract}

Kata Kunci: Pasta Ubi Jalar Ungu, Cookies, Karbohidrat, Serat, Diabetes Melitus

\section{ABSTRACT}

High fiber content in food will have a low glycemic index so that it can prolong gastric emptying. The presence of anthocyanin in food is also very important, because anthocyanin also has the ability to prevent disruption in liver function and reduce blood sugar levels. This study aims to analyze the effect of purple sweet potato paste substitution on chemical quality, energy value and organoleptic quality in cookies (pastries) as an alternative snack for people with diabetes mellitus. The type of this research was laboratory experiments with experimental design of Completely Randomized Design (CRD) with the level of treatment of purple sweet potato paste substitution: 24\%, 32\%, 40\%, and replication 3 times per treatment level. The statistical analysis used for chemical quality and energy is One Way Anova, and for organoleptic quality is Kruskall Wallis with a confidence level of 95\%. The results showed that the proportion of purple sweet potato paste used had a significant effect on water content, ash content, protein content, fat content, carbohydrate content, energy value and fiber content. The substitution of purple sweet potato paste has a significant influence on the color, aroma, texture, and taste of cookies. The treatment with the 
proportion of purple sweet potato paste is $40 \%$ (P3) with carbohydrate $(55.27 \mathrm{~g})$, the highest fiber $(2.81 \mathrm{~g})$ can be recommended as the best treatment level.

Keywords: Purple Sweet Potato Paste, Cookies, Carbohydrates, Fiber, Diabetes Mellitus

\section{PENDAHULUAN}

Masalah gizi yang terjadi di Indonesia adalah masalah gizi ganda yaitu gizi kurang dan gizi lebih. Tingginya prevalensi gizi kurang dapat menyebabkan turunnya imunitas tubuh dan meningkatnya penyakit infeksi. Peningkatan prevalensi gizi lebih berdampak pada meningkatnya penyakit degenerative, salah satunya adalah diabetes melitus (DM).

\section{Menurut International Diabetes} Federation (IDF) (2013) diprediksi adanya kenaikan jumlah penyandang DM (Diabetes Melitus) di Indonesia dari 9,1 juta pada tahun 2014 menjadi 14,1 juta pada tahun 2035. Berdasarkan Riskesdas (2013) prevalensi diabetes di Indonesia mengalami peningkatan dari 1,1 persen (2007) menjadi 2,1 persen (2013).

Penatalaksanaan diabetes melitus ada dua yaitu secara farmakologi dan non farmakologi. Pengelolaan diabetes melitus yang bersifat farmakologi dilakukan dengan pemberian obat, sedangkan yang bersifat non farmakologi dilakukan dengan pengaturan makan dan latihan jasmani (Manaf, 2008 dalam Mullyasari, 2015). Semakin rendah penyerapan karbohidrat, maka semakin rendah kadar glukosa darah. Kandungan serat yang tinggi dalam makanan akan mempunyai indeks glikemik yang rendah dan juga dapat memperpanjang pengosongan lambung (Witasari, dkk, 2009). Penderita diabetes melitus juga memerlukan antosianin untuk menurunkan kadar gula darahnya (Widowati, 2011). Salah satu bahan makanan rendah penyerapan karbohidrat, tinggi serat, dan mengandung antosianin adalah ubi jalar ungu. Widajati dkk. (2015) pada laporan hasil penelitiannya menyatakan bahwa ubi jalar ungu umur pasca panen 4 minggu dengan cara pengolahan dikukus mempunyai indeks glikemik (IG) dan beban glikemik rendah $(55,7$ dan 17,6).

Salah satu olahan dari ubi jalar ungu yang dapat dikembangkan adalah pasta ubi jalar ungu. Berdasarkan penelitian sebelumya yang telah dilakukan Hayati (2014) persentase maksimal substitusi pasta ubi jalar ungu pada pembuatan cookies adalah $70 \%$. Hal ini dikarenakan sifat cookies yang tidak terlalu keras, dan dengan semakin banyak substitusi pasta ubi jalar ungu akan menghasilkan cookies dengan tekstur 
sedikit lembek. Cookies ini mengandung lemak 19,8\%, kadar protein 10\%, kadar serat kasar 1\%, dan kadar antosianin 21,2 $\mathrm{mg} / 100 \mathrm{~g}$ bahan kering.

Konsumsi rata-rata cookies di kota besar dan pedesaan di Indonesia adalah 0,40 kg/kapita/tahun sehingga berpeluang untuk dikembangkan (Suarni, 2009 dalam Yulianti, 2015). Cookies yang dikenal dengan rasa manis ini tentu akan memberikan gambaran bahwa cookies tersebut tidak cocok untuk penderita diabetes melitus. Rasa manis pada cookies umumnya berasal dari gula pasir yang merupakan indeks glikemik tinggi dan dapat meningkatkan kadar gula darah tinggi.

Seiring dengan perkembangan ilmu pengetahuan dan teknologi, dilakukan berbagai inovasi dalam pembuatan cookies, salah satunya adalah cookies pasta ubi jalar ungu. Cookies substitusi pasta ubi jalar ungu ini diharapkan memiliki indeks glikemik rendah dan beban glikemik rendah yang dapat digunakan sebagai alternatif snack penderita diabetes melitus karena kandungan antosianin pada ubi jalar ungu dapat menurunkan kadar gula darah, sumber karbohidrat kompleks serta memiliki indeks glikemik dan beban glikemik rendah.

Adapun tujuan dari penelitian ini adalah menganalisis pengaruh substitusi pasta ubi jalar ungu terhadap mutu kimia, nilai energi, serat dan mutu organoleptik pada cookies (kue kering) sebagai alternatif snack penderita diabetes melitus.

\section{METODE PENELITIAN}

Penelitian ini menggunakan jenis penelitian eksperimen laboratorium dengan desain percobaan Rancangan Acak Lengkap (RAL). Perlakuan penelitian ini adalah substitusi pasta ubi jalar ungu pada cookies yang terdiri dari 4 taraf perlakuan. Taraf perlakuan dimulai dengan substitusi pasta ubi jalar ungu P0(100:0\%), dilanjut dengan P1(76:24\%), P2(68:32\%), dan P3(60: 40\%). Masing-masing taraf perlakuan diulang sebanyak 3 kali.

Penelitian ini dilaksanakan pada bulan Januari-Maret 2017 di laboratorium Jurusan Gizi Politenik Kesehatan Kemenkes Malang untuk pengolahan bahan, proses pembuatan pasta ubi jalar ungu, proses pembuatan cookies, dan penilaian mutu organoleptik dari cookies. Laboratorium Balai Penelitian Tanaman Aneka Kacang dan Umbi (Balitkabi) untuk analisis kadar air, kadar abu, kadar protein, kadar lemak cookies. Dan Laboratorium Pengujian Mutu dan 
Keamanan Pangan Universitas Brawijaya untuk analisis serat kasar cookies.

Bahan yang digunakan dalam pembuatan cookies meliputi : ubi jalar ungu, gula halus, gula tropicana slim, sweetener classic, mentega, telur ayam, tepung terigu, tepung maizena, tepung susu skim, vanili. Bahan yang digunakan untuk analisis : $\mathrm{NaOH}$-thio $40 \%, \mathrm{HCl}$ standar, $\mathrm{H}_{2} \mathrm{SO}_{4}$ pekat, Asam borat $4 \%$, aquadest, petroleum benzene, kertas saring, n-Hexane, $\mathrm{H}_{2} \mathrm{SO}_{4} 1,25 \%, \mathrm{NaOH}$ $3,25 \%$, etanol $96 \%$.

Alat yang digunakan dalam pembuatan cookies meliputi timbangan triple beam, baskom, mixer, rolling pin, loyang, sendok makan, sendok teh, panci, kompor, cetakan cookies, oven. Dan alat yang digunakan untuk analisis adalah: timbangan digital analitik, spatula, oven, desikator, penjepit, cawan porselin, tanur, labu kjeldahl, labu ukur, labu lemak, labu destilasi, soxhlet apparatus, erlenmeyer, cawan petri, beaker gelas, pipet volume, magnetic stirrer, kertas saring, pipet tetes, exstraktor soxlet, tabung reaksi.

\section{Tahapan Penelitian}

Penelitian dibagi atas dua tahap, yaitu penelitian pendahuluan dan utama. Penelitian pendahuluan bertujuan untuk menentukan jumlah bahan yang digunakan dalam pengolahan cookies serta menentukan nilai energi dan zat gizi lainnya (karbohidrat, protein, lemak, dan serat) optimal pada formulasi cookies substitusi pasta ubi jalar ungu. Penelitian utama meliputi pembuatan cookies, analisis proksimat, analisis energy, serat, uji organoleptik, dan uji taraf perlakuan terbaik.

\section{Metode Analisis}

Analisis yang dilakukan meliputi: kadar air, kadar abu, kadar protein dengan metode mikro Kjeldahl, kadar lemak dengan metode ekstraksi Soxhlet, kadar karbohidrat by difference, kadar serat (AOAC, 1990). Dan uji organoleptik dilakukan dengan metode Hedonic Scale menggunakan panelis dengan skala tingkat kesukaan (1) Sangat tidak suka, (2) Tidak suka, (3) Suka, (4) Sangat suka. Pemilihan perlakuan terbaik ditentukan dengan menghitung Indeks Efektifitas.

\section{HASIL DAN PEMBAHASAN}

\section{Kadar Air}

Kadar air pada produk cookies merupakan karakteristik kritis yang akan mempengaruhi penerimaan konsumen terhadap cookies, karena kadar air ini menentukan tekstur, terutama dalam hal atribut kelunakan/kelembutan (Lebuza 
dan Katz, 1981 dalam Hayati, 2014).

Hasil analisis kadar air cookies substitusi pasta ubi jalar ungu seperti pada Tabel 1.

Tabel 1. Kadar Air Cookies Per 100 gram

\begin{tabular}{|c|c|}
\hline $\begin{array}{c}\text { Taraf Perlakuan (\%) } \\
\text { (Tepung Terigu : Pasta Ubi } \\
\text { Jalar Ungu) }\end{array}$ & $\begin{array}{c}\text { Kadar Air } \\
(\%)\end{array}$ \\
\hline P0 $(100: 0)$ & $9,01^{\mathrm{b}}$ \\
\hline P1 $(76: 24)$ & $7,38^{\mathrm{a}}$ \\
\hline P2 $(68: 32)$ & $9,41^{\mathrm{bc}}$ \\
\hline P3 $(60: 40)$ & $8,08^{\mathrm{ab}}$ \\
\hline
\end{tabular}

Keterangan : Notasi yang berbeda menunjukkan adanya perbedaan yang signifikan $(\alpha=0,05)$.

Tabel 1 menunjukkan bahwa kadar air cookies substitusi pasta ubi jalar ungu berkisar antara 7,38-9,41\%. Kadar air pada empat taraf perlakuan tersebut melebihi syarat yang ditetapkan SNI 012973-1992 yaitu 4\%. Kadar air cookies tertinggi adalah pada perlakuan P2 $(9,41 \%)$ Hasil analisis statistik Oneway Anova pada tingkat kepercayaan 95\% menunjukkan bahwa penggunaan proporsi pasta ubi jalar ungu yang berbeda dapat memberikan pengaruh yang signifikan $(\mathrm{p}=0,020)$ terhadap kadar air cookies. Hasil analisis lanjut, Duncan Multiple Range Test (DMRT) menunjukkan bahwa substitusi pasta ubi jalar ungu kontrol (P0) berbeda secara signifikan dengan perlakuan (P1), dan perlakuan (P1) berbeda signifikan dengan perlakuan (P2). Tingginya dan berbedanya kadar air pada cookies masing-masing tarap perlakuan tersebut dikarenakan penggunaan pasta ubi jalar ungu dengan proporsi yang berbeda dan ubi jalar ungu mempunyai kadar air yang relatif tinggi.

\section{Kadar Abu}

Kandungan mineral total dalam bahan pangan dapat diperkirakan sebagai kandungan abu yang merupakan residu an-organik yang tersisa setelah bahanbahan organik terbakar habis. Semakin banyak kandungan mineralnya maka kadar abu menjadi tinggi begitu juga sebaliknya apabila kandungan mineral sedikit maka kadar abu bahan juga sedikit (Sudarmaji, Slamet, 2006). Hasil analisis kadar abu cookies substitusi pasta ubi jalar ungu disajikan pada Tabel 2.

Tabel 2. Kadar Abu Cookies Per 100 gram

\begin{tabular}{|c|c|}
\hline $\begin{array}{c}\text { Taraf Perlakuan }(\%) \\
\text { (Tepung Terigu : Pasta Ubi } \\
\text { Jalar Ungu) }\end{array}$ & $\begin{array}{c}\text { Kadar Abu } \\
(\%)\end{array}$ \\
\hline P0 $(100: 0)$ & $1,91^{\mathrm{a}}$ \\
\hline P1 $(76: 24)$ & $2,46^{\mathrm{b}}$ \\
\hline P2 $(68: 32)$ & $2,44^{\mathrm{b}}$ \\
\hline P3 $(60: 40)$ & $2,25^{\mathrm{c}}$ \\
\hline
\end{tabular}

Keterangan : Notasi yang berbeda menunjukkan adanya perbedaan yang signifikan $(\alpha=0,05)$.

Tabel 2 menunjukkan bahwa kadar abu cookies substitusi pasta ubi jalar ungu berkisar antara 1,91 - 2,46\%. Kadar abu cookies menurut SNI 01-2973-1992 yaitu maksimal 2\%, sehingga cookies substitusi pasta ubi jalar ungu pada tarap perlakuan P1, P2, dan P3 memiliki kadar abu melebihi standar yang ditetapkan SNI 01- 
2973-1992. Hasil analisis statistik Oneway

Anova pada tingkat kepercayaan 95\% menunjukkan bahwa proporsi pasta ubi jalar ungu memberikan pengaruh yang singnifikan $(\mathrm{p}=0,000)$ terhadap kadar abu cookies substitusi ubi jalar ungu. Hasil analisis lanjut, Duncan Multiple Range Test (DMRT) menunjukkan bahwa substitusi pasta ubi jalar ungu kontrol (P0) berbeda signifikan dengan perlakuan (P1, $\mathrm{P} 2$, dan P3), dan taraf perlakuan (P1 dan P2) berbeda signifikan dengan perlakuan (P3). Perbedaan kadar abu tersebut disebabkan karena penggunaan proporsi pasta ubi jalar yang berbeda-beda dan adanya kandungan mineral yang terdapat pada ubi jalar ungu. Mineral yang terdapat pada ubi jalar ungu yaitu kalsium 30 $\mathrm{mg} / 100 \mathrm{~g}$ bahan, Fosfor $49 \mathrm{mg} / 100 \mathrm{~g}$ bahan, Zat Besi 0,7 mg/100 g bahan (Direktorat Gizi Depkes RI, 1981 dalam Gartika, 2007).

\section{Kadar Protein}

Protein merupakan suatu zat makanan yang amat penting bagi tubuh, kekurangan protein dalam waktu lama dapat mengganggu berbagai proses dalam tubuh dan menurunkan daya tahan tubuh terhadap penyakit (Winarno, 2004). Hasil analisis kadar protein cookies substitusi pasta ubi jalar ungu seperti pada Tabel 3.
Tabel 3. Kadar Protein Cookies Per 100 gram.

\begin{tabular}{|c|c|}
\hline $\begin{array}{c}\text { Taraf Perlakuan }(\%) \\
\text { (Tepung Terigu : Pasta } \\
\text { Ubi Jalar Ungu) }\end{array}$ & $\begin{array}{c}\text { Kadar } \\
\text { Protein }(\%)\end{array}$ \\
\hline P0 $(100: 0)$ & $12,40^{\mathrm{a}}$ \\
\hline P1 $(76: 24)$ & $13,31^{\mathrm{b}}$ \\
\hline P2 $(68: 32)$ & $13,33^{\mathrm{b}}$ \\
\hline P3 $(60: 40)$ & $13,66^{\mathrm{b}}$ \\
\hline
\end{tabular}

Keterangan : Notasi yang berbeda menunjukkan adanya perbedaan yang signifikan $(\alpha=0,05)$.

Tabel 3 menunjukkan bahwa kadar protein cookies substitusi pasta ubi jalar ungu berkisar antara 12,40-13,66\%. Kadar protein pada produk cookies substitusi pasta ubi jalar ungu telah memenuhi syarat yang ditetapkan SNI 012973-1992 yaitu minimal 6\%. Hasil analisis statistik Oneway Anova pada tingkat kepercayaan $95 \%$ menunjukkan bahwa substitusi pasta ubi jalar ungu memberikan pengaruh yang signifikan $(\mathrm{p}=0,000)$ terhadap kadar protein cookies substitusi ubi jalar ungu. Hasil analisis lanjut, Duncan Multiple Range Test (DMRT) menunjukkan bahwa substitusi pasta ubi jalar ungu kontrol (P0) berbeda signifikan dengan taraf perlakuan (P1, P2, dan P3). Tingginya kadar protein ini berkaitan dengan bahan yang digunakan dalam pembuatan cookies yaitu tepung susu skim, dimana tepung susu skim mengandung protein yang tinggi yaitu sebesar 36,4\% (Foodtechnology13, 2017). 


\section{Kadar Lemak}

Lemak dalam pangan memberi kepuasan cita rasa, menimbulkan rasa dan keharuman pada makanan, sebagai agen pengemulsi, seperti lesitin, selain itu lemak pangan merupakan sumber penyedia asam lemak esensial yang penting bagi tubuh, yaitu asam linoleat dan asam linolenat (Soediatama, 1985).

Hasil analisis kadar lemak cookies substitusi pasta ubi jalar ungu disajikan pada Tabel 4.

Tabel 4. Kadar Lemak Cookies Per 100 gram

\begin{tabular}{|c|c|}
\hline $\begin{array}{c}\text { Taraf Perlakuan (\%) } \\
\text { (Tepung Terigu : Pasta } \\
\text { Ubi Jalar Ungu) }\end{array}$ & $\begin{array}{c}\text { Kadar } \\
\text { Lemak }(\%)\end{array}$ \\
\hline P0 $(100: 0)$ & $12,64^{\mathrm{a}}$ \\
\hline P1 $(76: 24)$ & $13,85^{\mathrm{b}}$ \\
\hline P2 $(68: 32)$ & $13,84^{\mathrm{b}}$ \\
\hline P3 $(60: 40)$ & $17,74^{\mathrm{c}}$ \\
\hline
\end{tabular}

Keterangan : Notasi yang berbeda menunjukkan adanya perbedaan yang signifikan $(\alpha=0,05)$.

Tabel 4 menunjukkan bahwa kadar lemak cookies substitusi pasta ubi jalar ungu berkisar antara 12,64 - 17,74 g/100 g. Kadar lemak yang dihasilkan cookies substitusi pasta ubi jalar ungu pada kontrol (P0) dan taraf perlakuan (P1, P2, P3) belum memenuhi syarat SNI 01-29731992 yaitu kadar lemak minimal 18\%. Hasil analisis statistik Oneway Anova pada tingkat kepercayaan $95 \%$ menunjukkan bahwa proporsi pasta ubi jalar ungu memberikan pengaruh yang singnifikan $(p=0,000)$ terhadap kadar lemak cookies substitusi ubi jalar ungu. Hasil analisis lanjut, Duncan Multiple Range Test (DMRT) menunjukkan bahwa kadar lemak cookies substitusi pasta ubi jalar ungu kontrol (P0) berbeda signifikan dengan perlakuan (P1, P2, dan P3), dan taraf perlakuan (P1 dan P2) berbeda signifikan dengan perlakuan (P3). Kadar lemak pada cookies sudah cukup tinggi, dan lemak yang tertinggi didapat pada cookies taraf perlakuan P3 (17,74\%). Adanya penambahan mentega untuk pengolesan dalam loyang agar cookies tidak lengket, perlakuan tersebut diduga menaikkan kadar lemak dalam produk cookies.

\section{Kadar Karbohidrat}

Menurut Almatsier (2009) fungsi karbohidrat yaitu sebagai sumber energi, pemberi rasa manis pada makanan, penghemat protein, mengatur metabolisme lemak, dan membantu pengeluaran feses. Untuk memelihara kesehatan, WHO (1990) menganjurkan agar $55-75 \%$ konsumsi energi total berasal dari karbohidrat kompleks dan paling banyak hanya $10 \%$ berasal dari gula sederhana. Hasil analisis kadar protein cookies substitusi pasta ubi jalar ungu disajikan pada Tabel 5. 
Tabel 5. Kadar Karbohidrat Cookies Per 100 gram

\begin{tabular}{|c|c|}
\hline $\begin{array}{c}\text { Taraf Perlakuan }(\%) \\
\text { (Tepung Terigu : Pasta } \\
\text { Ubi Jalar Ungu) }\end{array}$ & $\begin{array}{c}\text { Kadar } \\
\text { Karbohidrat } \\
(\%)\end{array}$ \\
\hline P0 $(100: 0)$ & $64,05^{\mathrm{a}}$ \\
\hline P1 $(76: 24)$ & $63,01^{\mathrm{a}}$ \\
\hline P2 $(68: 32)$ & $60,99^{\mathrm{b}}$ \\
\hline P3 $(60: 40)$ & $58,27^{\mathrm{c}}$ \\
\hline
\end{tabular}

Keterangan : Notasi yang berbeda menunjukkan adanya perbedaan yang signifikan $(\alpha=0,05)$.

Tabel 5 menunjukkan bahwa kadar

karbohidrat cookies substitusi pasta ubi jalar ungu berkisar antara 58,27-64,05\% .

Kadar karbohidrat yang dihasilkan cookies substitusi pasta ubi jalar ungu kontrol dan semua taraf perlakuan berada dibawah syarat SNI 01-2973-1992 yaitu kadar karbohidrat minimal 70\%. Hasil analisis statistik Oneway Anova pada tingkat kepercayaan 95\% menunjukkan bahwa proporsi pasta ubi jalar ungu memberikan pengaruh yang singnifikan $(\mathrm{p}=0,000)$ terhadap kadar karbohidrat cookies substitusi ubi jalar ungu. Hasil analisis lanjut, Duncan Multiple Range Test (DMRT) menunjukkan bahwa substitusi pasta ubi jalar ungu kontrol (P0) dan taraf perlakuan P1 berbeda signifikan dengan taraf perlakuan (P2 dan P3), dan taraf perlakuan P2 berbeda signifikan dengan taraf perlakuan P3. Semakin tinggi substitusi pasta ubi jalar ungu maka kadar karbohidrat cookies substitusi pasta ubi jalar ungu cenderung menurun. Kadar karbohidrat dari cookies ini dipengaruhi oleh besarnya kadar air, kadar abu, kadar lemak dan kadar protein yang terdapat pada cookies. Semakin besar nilai penjumlahan antara kadar air, kadar abu, kadar lemak dan kadar protein, maka semakin kecil kadar karbohidart yang terdapat pada cookies.

\section{Kadar Serat}

Serat didefinisikan sebagai bagian dari komponen bahan pangan nabati yang tidak dapat dicerna oleh saluran pencernaan manusia (Winarno, 2004).

Tabel 6. Kadar Serat Cookies Per 100 gram

\begin{tabular}{|c|c|}
\hline $\begin{array}{c}\text { Taraf Perlakuan }(\%) \\
\text { (Tepung Terigu : Pasta } \\
\text { Ubi Jalar Ungu) }\end{array}$ & $\begin{array}{c}\text { Rata-rata } \\
\text { Kadar } \\
\text { Serat }(\%)\end{array}$ \\
\hline P0 $(100: 0)$ & $1,61^{\mathrm{a}}$ \\
\hline P1 $(76: 24)$ & $2,99^{\mathrm{b}}$ \\
\hline P2 $(68: 32)$ & $1,94^{\mathrm{c}}$ \\
\hline P3 $(60: 40)$ & $2,81^{\mathrm{d}}$ \\
\hline
\end{tabular}

Keterangan : Notasi yang berbeda menunjukkan adanya perbedaan yang signifikan $(\alpha=0,05)$.

Tabel 6 menunjukkan bahwa kadar serat cookies substitusi pasta ubi jalar ungu berkisar antara 1,61 -2,99\%. Kadar serat cookies substitusi pasta ubi jalar ungu pada seluruh taraf perlakuan melebihi syarat SNI 01-2973-1992 yang ditetapkan yaitu maksimal 0,5\%. Hasil analisis statistik Oneway Anova pada tingkat kepercayaan $95 \%$ menunjukkan bahwa proporsi pasta ubi jalar ungu memberikan pengaruh yang singnifikan 
$(\mathrm{p}=0,000)$ terhadap kadar serat kasar cookies substitusi ubi jalar ungu. Hasil analisis lanjut, Duncan Multiple Range Test (DMRT) menunjukkan bahwa substitusi pasta ubi jalar ungu pada kontrol (P0) dan semua taraf perlakuan (P1, P2, dan P3) menunjukan adanya pengaruh yang signifikan. Hal ini dikarenakan ubi jalar ungu memiliki kandungan serat yang cukup tinggi. Kandungan serat kasar dari pasta ubi jalar ungu adalah 2,16\% (Yasni, dkk, 2016). Makanan yang mengandung serat tinggi dapat menyebabkan makanan lebih lama tertahan di lambung sehingga rasa kenyang lebih panjang (Nintami, 2012). Keberadaan serat pangan dapat mempengaruhi kadar glukosa darah (Fernandes et al. 2005 dalam Arif, dkk., 2013). Secara umum, kandungan serat pangan yang tinggi berkontribusi pada nilai indeks glikemik (IG) yang rendah (Trinidad et al. 2010 dalam Arif, dkk., 2013).

\section{Nilai Energi}

Energi diperoleh dari karbohidrat, lemak, dan protein yang ada di dalam bahan makanan. Analisis energi menggunakan faktor Atwater, yaitu perubahan dari 1 gram karbohidrat, protein, dan lemak berturut-turut menghasilkan 4, 4, dan 9 kkal energi. (Almatsier, 2009).

Tabel 7. Nilai Energi Cookies Per 100 gram.

\begin{tabular}{|c|c|}
\hline $\begin{array}{c}\text { Taraf Perlakuan (\%) } \\
\text { Tepung Terigu : Pasta Ubi } \\
\text { Jalar Ungu) }\end{array}$ & $\begin{array}{c}\text { Rata-rata } \\
\text { Nilai Energi } \\
\text { (Kalori) }\end{array}$ \\
\hline P0 (100:0) & $419,54^{\mathrm{a}}$ \\
\hline P1 $(76: 24)$ & $429,86^{\mathrm{b}}$ \\
\hline P2 $(68: 32)$ & $421,79^{\mathrm{a}}$ \\
\hline P3 $(60: 40)$ & $447,38^{\mathrm{c}}$ \\
\hline
\end{tabular}

Keterangan : Notasi yang berbeda menunjukkan adanya perbedaan yang signifikan $(\alpha=0,05)$.

Tabel 7 menunjukkan bahwa nilai energi cookies substitusi pasta ubi jalar ungu berkisar antara 419,54-447,38 kalori/100g. Nilai energi baik kontrol dan semua taraf perlakuan cookies substitusi pasta ubi jalar ungu di atas syarat SNI 012973-1992 yang ditetapkan yaitu minimal 400 kalori/100 g. Nilai energi cookies substitusi pasta ubi jalar ungu mengalami kenaikan seiring dengan semakin meningkatnya proporsi pasta ubi jalar ungu yang digunakan. Hasil analisis statistik Oneway Anova pada tingkat kepercayaan 95\% menunjukkan bahwa proporsi pasta ubi jalar ungu memberikan pengaruh yang singnifikan $(\mathrm{p}=0,000)$ terhadap nilai energi cookies substitusi ubi jalar ungu. Hasil analisis lanjut, Duncan Multiple Range Test (DMRT) menunjukkan bahwa substitusi pasta ubi jalar ungu pada P0 berbeda signifikan dengan taraf perlakuan (P1 dan P3), dan 
perlakuan (P1) berbeda secara signifikan dengan taraf perlakuan (P2 dan P3).

\section{MUTU ORGANOLEPTIK}

Tabel 8. Tingkat Kesukaan Panelis terhadap Warna, Aroma, Rasa, dan Tekstur Cookies Substitusi Pasta Ubi Jalar Ungu.

\begin{tabular}{|c|c|c|c|c|}
\hline $\begin{array}{c}\text { Taraf Perlakuan (\%) } \\
\text { (Tepung Terigu : Pasta Ubi Jalar } \\
\text { Ungu) }\end{array}$ & Warna & Aroma & Tekstur & Rasa \\
\hline P0 (100:0) & $3,35^{\mathrm{a}}$ & $3,30^{\mathrm{a}}$ & $2,55^{\mathrm{ac}}$ & $2,35^{\mathrm{a}}$ \\
\hline P1 $(76: 24)$ & $2,20^{\mathrm{b}}$ & $2,40^{\mathrm{b}}$ & $2,55^{\mathrm{ac}}$ & $2,35^{\mathrm{a}}$ \\
\hline P2 $(68: 32)$ & $2,60^{\mathrm{b}}$ & $3,15^{\mathrm{a}}$ & $2,05^{\mathrm{a}}$ & $2,90^{\mathrm{b}}$ \\
\hline P3 $(60: 40)$ & $3,45^{\mathrm{a}}$ & $3,15^{\mathrm{a}}$ & $2,85^{\mathrm{bc}}$ & $3,15^{\mathrm{b}}$ \\
\hline
\end{tabular}

Notasi yang berbeda menunjukkan adanya perbedaan yang signifikan $(\alpha=0,05)$

Keterangan: 4=sangat suka; $3=$ suka, $2=$ tidak suka; $1=$ sangat tidak suka

\section{Warna}

Tingkat kesukaan panelis terhadap warna cookies substitusi pasta ubi jalar ungu (Tabel 8) rata-rata berkisar 2,203,45 berdasarkan skala hedonik 1-4 (sangat tidak suka - sangat suka). Tingkat kesukaan panelis terhadap warna cookies substitusi pasta ubi jalar ungu cenderung meningkat seiring dengan peningkatan proporsi pasta ubi jalar ungu, dan yang paling disukai adalah taraf perlakuan P3 (rata-rata 3,45). Hal ini disebabkan karena peningkatan substitusi pasta ubi jalar ungu menghasilkan warna ungu kecoklatan. Warna ungu tersebut berasal dari pasta ubi jalar ungu yang memiliki warna ungu kehitaman (ungu pekat) yang disebabkan oleh pigmen antosianin. Sedangkan warna coklat tersebut dapat berasal dari kandungan protein pada bahan yang menyebabkan reaksi Maillard, serta proses karamelisasi yang terjadi karena pemanasan. Hasil analisis statistik Kruskal Wallis pada tingkat kepercayaan 95\% menunjukkan bahwa substitusi pasta ubi jalar ungu memberikan pengaruh yang signifikan $(\mathrm{p}=0,000)$ terhadap warna cookies. Hasil analisis lanjut, Mann Whitney menunjukkan bahwa P0 berbeda signifikan dengan taraf perlakuan P1 dan $\mathrm{P} 2$. Dan taraf perlakuan P1 dan P2 berbeda signifikan dengan taraf perlakuan P3.

\section{Aroma}

Tingkat kesukaan panelis terhadap aroma cookies substitusi pasta ubi jalar ungu (Tabel 8) berkisar 2,40-3,30 dengan tingkat kesukaan tertinggi pada kontrol (P0). Terjadi peningkatan kesukaan panelis terhadap aroma cookies substitusi pasta ubi jalar ungu dari perlakuan P1 $(2,40)$ menjadi 3,15 pada perlakuan P2 dan P3. Peningkatan substitusi pasta ubi 
jalar ungu menghasilkan aroma khas ubi. Aroma khas ubi jalar ungu ini berasal dari kandungan pati yang terdegradasi. Aroma cookies substitusi pasta ubi jalar ungu juga beraroma susu. Aroma susu ini berasal dari salah satu bahan untuk membuat cookies yaitu susu skim. Hasil analisis statistik Kruskal Wallis pada tingkat kepercayaan 95\% menunjukkan bahwa substitusi pasta ubi jalar ungu memberikan pengaruh yang signifikan $(\mathrm{p}=0,001)$ terhadap aroma cookies. Hasil analisis lanjut, Mann Whitney menunjukkan bahwa P0 berbeda signifikan dengan taraf perlakuan P1, dan taraf perlakuan P1 berbeda signifikan dengan taraf perlakuan P2 dan P3.

\section{Tekstur}

Tingkat kesukaan panelis terhadap tekstur cookies substitusi pasta ubi jalar ungu (Tabel 8) berkisar 2,05- 2,85, dengan tingkat kesukaan tertinggi (paling disukai) adalah P3 (rata-rata 2,85). Tingkat kesukaan panelis terhadap tekstur cookies substitusi pasta ubi jalar ungu berbeda antara masing-masing taraf perlakuan. Kadar air yang tinggi pada produk cookies substitusi pasta ubi jalar ungu berpengaruh terhadad tekstur cookies. Menurut Soeparno (1994) bahwa faktor utama yang menyebabkan tingginya kadar air produk adalah kadar air bahan baku, sehingga akan berpengaruh pada pembentukan tekstur produk akhir. Hasil analisis statistik Kruskal Wallis pada tingkat kepercayaan 95\% menunjukkan bahwa substitusi pasta ubi jalar ungu memberikan pengaruh yang signifikan ( $p=0,023)$ terhadap tekstur cookies. Hasil analisis lanjut, Mann Whitney menunjukkan bahwa taraf perlakuan P2 berbeda signifikan dengan taraf perlakuan P3.

\section{Rasa}

Tingkat kesukaan panelis terhadap rasa cookies substitusi pasta ubi jalar ungu (Tabel 8) berkisar 2,35-3,15 dengan P3 merupakan perlakuan yang paling disukai (rata-rata penerimaan 3,15).

Tingkat kesukaan panelis terhadap rasa cookies substitusi pasta ubi jalar ungu cenderung meningkat seiring dengan peningkatan proporsi pasta ubi jalar ungu, semakin tinggi proporsi pasta ubi jalar ungu maka rasa cookies semakin manis. Rasa manis dari cookies berasal dari gula sebagai bahan untuk membuat cookies dan berasal dari pasta ubi jalar ungu yang juga menambah rasa manis pada cookies. Penambahan lemak pada pembuatan cookies juga berpengaruh terhadap cita rasa cookies. Hal ini sesuai dengan 
pernyataan Sultan (1981) dalam Yulianti (2015) bahwa lemak, minyak, dan shortening lainnya digunakan dalam pembuatan cookies dengan beberapa alasan diantaranya memberikan rasa berlemak dan keempukan produk, memperbaiki eating quality product (rasa, warna, kenampakan fisik dan nilai gizi), menambah flavor. Hasil analisis statistik Kruskal Wallis pada tingkat kepercayaan 95\% menunjukkan bahwa substitusi pasta ubi jalar ungu memberikan pengaruh yang signifikan $(\mathrm{p}=0,003)$ terhadap tekstur cookies. Hasil analisis lanjut, Mann Whitney menunjukkan bahwa perlakuan kontrol P0 dan taraf perlakuan P1 berbeda signifikan dengan taraf perlakuan P2 dan P3.

\section{Penentuan Taraf Perlakuan Terbaik}

Penentuan taraf perlakuan terbaik menggunakan parameter kadar karbohidrat, serat dan mutu organoleptik (warna, aroma tekstur, rasa). Berdasarkan parameter yang digunakan untuk penentuan perlakuan terbaik, diperoleh cookies substitusi pasta ubi jalar ungu dengan proporsi $40 \%$ (P3) sebagai taraf perlakuan terbaik cookies, dengan karbohidrat $(55,27 \mathrm{~g})$, serat $(2,81 \mathrm{~g})$, dan dengan daya terima organoleptik (warna, aroma dan rasa) rata-rata dengan skala suka. Kadar karbohidrat dan serat merupakan variabel terpenting dalam menentukan tarap perlakuan terbaik dari cookies substitusi pasta ubi jalar ungu. Sumber karbohidrat yang berasal dari ubi jalar ungu merupakan jenis karbohidrat kompleks. Juwita (2012) menyatakan bahwa jenis karbohidrat kompleks merupakan karbohidrat yang dipecah dengan lambat yaitu memiliki indeks glikemik rendah sehingga melepaskan glukosa ke dalam darah dengan lambat. Demikian juga dengan keberadaan serat pangan dapat mempengaruhi kadar glukosa darah (Fernandes et al. 2005 dalam Arif, dkk., 2013). Secara umum, kandungan serat pangan yang tinggi berkontribusi pada nilai IG yang rendah (Trinidad et al. 2010 dalam Arif, dkk., 2013). Serat dapat memperlambat laju makanan pada saluran pencernaan dan menghambat aktivitas enzim sehingga proses pencernaan khususnya pati menjadi lambat dan respons glukosa darah pun akan lebih rendah, dan dengan demikian IG-nya cenderung lebih rendah (Arif, dkk., 2013).

\section{KESIMPULAN}

Peningkatan substitusi pasta ubi jalar ungu memberikan pengaruh yang signifikan terhadap kadar air, kadar abu, 
kadar lemak, kadar karbohidrat dan kadar serat.

Substitusi pasta ubi jalar ungu memberikan pengaruh yang signifikan terhadap warna, aroma, tekstur, dan rasa pada cookies.

Untuk perlakuan terbaik cookies substitusi pasta ubi jalar ungu adalah proporsi $40 \%$ (P3) dengan karbohidrat $(55,27 \mathrm{~g})$, serat $(2,81 \mathrm{~g})$.

\section{Saran}

Cookies substitusi pasta ubi jalar ungu dengan proporsi tepung terigu : pasta ubi jalar ungu dengan proporsi 40\% (P3) dapat digunakan sebagai alternatif snack penderita diabetes melitus.

\section{DAFTAR PUSTAKA}

Almatsier, S. (2009). Prinsip Dasar Ilmu Gizi. Jakarta: PT Gramedia Pustaka Utama.

AOAC (Association of Official Analytical Chemist), (1990). Official Methods of Analysis. Association of Official Analytical Chemists. AOAC, Washington DC, USA.

Arif, A. B., dkk. (2013). Nilai Indeks Glikemik Produk Pangan dan FaktorFaktor yang Mempengaruhinya. Balai Besar Penelitian dan Pengembangan Pascapanen Pertanian: J. Litbang Pert. Vol. 32 No. 3.

Foodtechnology13. (2017). Roti, Kue, dan Bakery, (Online), (foodtechnology13.wordpress.com/rotikue-dan-bakery/cookies/), diakses 5 Juni 2017.
Gartika, I. R. (2007). Kajian Penggunaan Tepung Ubi Jalar Ungu pada Produk Kue Semprit sebagai Produk Unggulan yang Berpotensi sebagai Makanan Fungsional. Skripsi: fakultas Teknik Universitas Negeri Yogyakarta.

Hayati, S. R. (2014). Pembuatan Cookies dari Pasta Ubi Jalar Ungu (Ipomea batatas L.)dengan Penambahan Tepung Kacang Hijau. Skripsi: Fakultas Pertanian Universitas Syiah Kuala, Banda Aceh.

International Diabetes Federation (IDF). (2013). IDF Diabetes Atlas Sixth Edition.

Juwita. (2012). Formulasi dan Nilai Indeks Glikemik Cookies Ganyong (Canna Edulis Kerr.). Skripsi: Departemen Gizi Masyarakat, Fakultas Ekologi Manusia Institut Pertanian Bogor.

Mullyasari, H. (2015). Pengaruh Pemberian Susu Kedelai Hitam (Glycine Soja) terhadap Penurunan Kadar Glukosa Darah Tikus Model Diabetes Melitus Tipe 2 yang Diinduksi dengan Streptozotocin. Karya Tulis Akhir.

Nintami, A. L. (2012). Kadar Serat, Aktivitas Antioksidan, Amilosa, dan Uji Kesukaan Mi Basah dengan Substitusi Tepung Ubi Jalar Ungu (Ipomea batatas var Ayumurasaki) bagi Penderita Diabetes Melitus Tipe 2. Artikel Penelitian: Program Studi Ilmu Gizi - Universitas Diponegoro.

Sediaoetama; Achmad, D. (1985). Ilmu Gizi untuk Mahasiswa dan Profesi Jilid 1. Jakarta: Dian Rakyat.

Soeparno. (1994). Ilmu dan Teknologi Daging. Yogyakarta: Gadjah Mada Press.

Standart Nasional Indonesia. SNI 01-2973 (1992). Syarat Mutu Biskuit.

Sudarmadji, Slamet,dkk. (2006). Prosedur Analisis Untuk Bahan Makan Dan Pertanian. Yogyakarta: Liberty.

Winarno, F. G. (2004). Kimia Pangan dan Gizi. Jakarta: Gramedia Pustaka Utama. 
Witasari, U. (2009). Hubungan Tingkat Pengetahuan, Asupan Karbohidrat dan Serat dengan Pengendalian Kadar Glukosa Darah pada Penderita Diabetes Melitus Tipe 2. Jurnal Penelitian Sains \& Teknologi, Vol.10, No. 2, 2009: 130 - 138.

Widowati, S. (2011). Difersifikasi Konsumsi Pangan Berbasis Ubi Jalar. Vol. 20(1):49-61.

Widajati, E.,Puspita, T. Suwita, K. (2015). Mutu Gizi, Indeks Glikemik dan Beban Glikemik Ubi Jalar sebagai Alternatif Sumber Karbohidrat Bagi Penderita Diabetes Melitus. Laporan Penelitian Hibah Bersaing Kode: 354/Ilmu Gizi.
Yulianti, F. (2015). Karakteristik dan Kesesuaian Atribut Mutu Cookies Soyaba (Soya-Banana) dari Tepung Kedelai Anjasmoro, Baluran dan Impor dengan Penambahan Pisang Mas. Skripsi: Program Studi Teknologi Hasil Pertanian (S1) dan Sarjana Teknologi Pertanian, Universitas Jember, Jember.

Yasni., dkk. (2009). Pemanfaatan Ubi Jalar Ungu sebagai Bahan Produk Pangan Fungsional. Ringkasan Eksekutif: Kerjasama Kemitraan Penelitian Pertanian dengan Perguruan Tinggi (KKPT). 